Review Article

\title{
Understanding whether Air Filtration from Air Conditioners Reduces the Probability of Virus Transmission in the Environment
}

\author{
Shalom Akhai', Shaveta Mala' ${ }^{2}$ A Anderson Jerin ${ }^{3}$ \\ 1,3 Mechanical Engineering Department, C.E.C. Jhanjeri, Punjab, India. \\ ${ }^{2}$ Anaesthesia Department, Government Multi-Specialty Hospital, Sector-16, Chandigarh, India. \\ DOI: https://doi.org/10.24321/2394.6539.202109
}

\section{I $\quad \mathbf{N} \quad \mathbf{F} \quad \mathbf{O}$}

E-mail Id:

shalomakhai@gmail.com

Orcid Id:

https://orcid.org/0000-0002-7533-457X

How to cite this article:

Akhai S, Mala S, Jerin AA. Understanding whether Air Filtration from Air Conditioners Reduces the Probability of Virus Transmission in the Environment. J Adv Res Med Sci Tech. 2021;8(1):36-41.

Date of Submission: 2021-03-02

Date of Acceptance: 2021-03-28

\section{$\begin{array}{llllllllllllll}\mathbf{A} & \mathbf{B} & \mathbf{S} & \mathbf{T} & \mathbf{R} & \mathbf{A} & \mathbf{C} & \mathbf{T}\end{array}$}

As the COVID-19 global pandemic continues to remain severe, people tend to spend more time in an indoor dwelling and, much of the time in the summer, people choose to sit at air-conditioned homes, offices, or travel in air-conditioned vehicles. In order to reduce the occurrence of health-care-related diseases, cleaning and disinfecting of such environment is critical as polluted air posed threat to human wellbeing, reduces the life expectancy due to cardiovascular and respiratory diseases, including asthma and pulmonary disease. People are less aware of disease transmission through air circulation in the air-conditioned environment. In particular, in the current times, virus particles, in addition to the various technological advancements such as the use of HEPA filters, appear to pass through the air from a person to the other. The present work examines the indexed publications in this area. The authors in this report have attempted to collect reports and studies on the HVAC system and the virus in order to get its illustration. The air filtration devices i.e. High Efficiency Particulate Air (HEPA) filters were found to play an important role in damping the rate of transmission of viruses.

Keywords: Corona Virus, Air-Conditioners, Pandemic

\section{Introduction \& Background}

The Air-conditioners we use at our home and other office spaces have air filters in them. ${ }^{1}$ It remains a question in ones mind that whether these filters are enough to stop the virus from entering our rooms or not. ${ }^{2}$ To explore this we need to understand few basic concepts regarding the size of the filters along with the size of the particles especially coronavirus which is spreading nowadays.

There are some reports which suggest that the corona virus is airborne. ${ }^{3}$ Studies show that the virus can be airborne from an infected person to up to 1.5 metre (or 9 feet). This distance is for persons who are static and are not undergoing any motion. The distance increases to a staggering 20.1 metre (or 66 feet) when walking, running or cycling. Another study says that the virus can survive for more than 2 days on shiny surfaces like stainless steel surface. The study also states that the virus can remain active for more than a couple of hours even on disinfected surface. ${ }^{4}$

The biggest challenge we face here is basic survival. How will we be able to overcome this virus? Or will the virus infect us all and take us to the graveyard. At present we are living in a state of uncertainty as COVID particles effect tact. ${ }^{5}$ Cardiovascular and respiratory diseases reduce life 
expectancy. ${ }^{6}$ We are not sure what to touch? What to breathe? What to eat? And it is all because of something we cannot even see. We are the human race who considered ourselves to be the strongest of all the creature living on this planet earth. But how is it possible that we did not consider that even something as tiny as a virus can bring us to our knees. Now that it has happened, we are all frightened of even stepping out of our homes. One of the many worries which needs proper explanation is the use of air-conditioners at this time. ${ }^{2}$

\section{Review}

There have also been researches on the COVID-19 particles. A summary of the various studies would give us more insights into the size and the ability of the particle in passing through different barriers. While the particles travel through the air filtration system of air conditioners employed with HEPA filters, they're captured and retained within the filter. From a survey of the past studies to understand the different advantages/drawbacks of the system using HEPA filters few studies have been listed in Table 1.

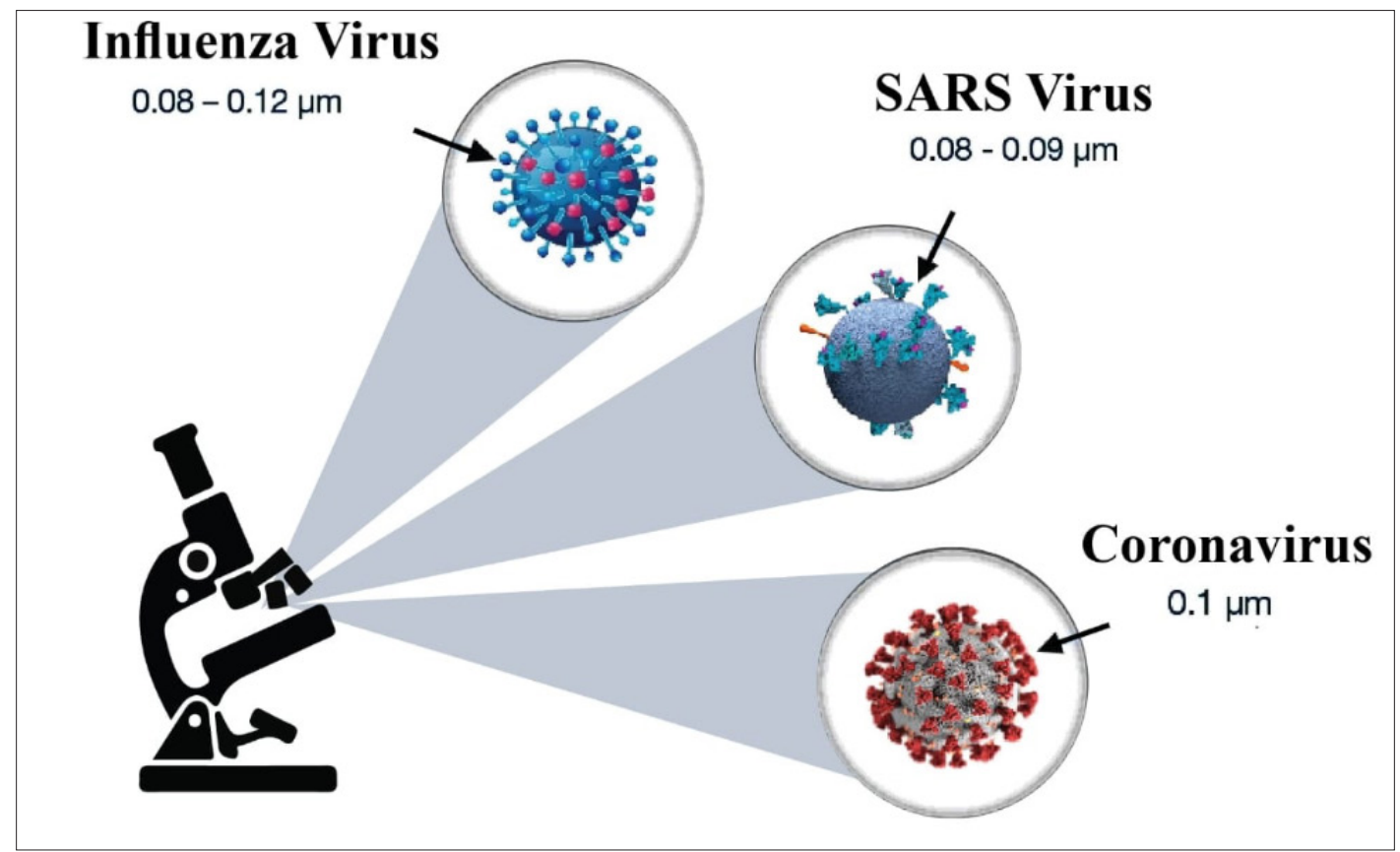

Figure I.Size of the virus as opposed to others ${ }^{16}$

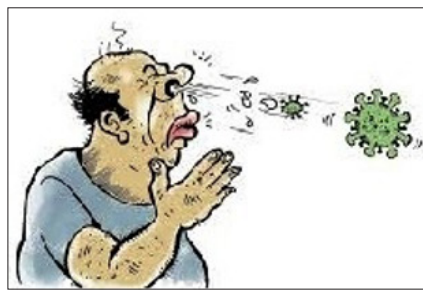

As airbone droplets

m.

On porous surfaces

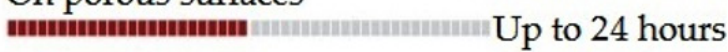

On metallic surfaces

Around 3 days

Figure 2.Survival time of coronavirus on different surfaces ${ }^{4}$

Table I.Past studies on the use of HEPA filters and the inferences which may require further works

\begin{tabular}{|c|c|c|c|}
\hline $\begin{array}{c}\text { Source } \\
\text { [Reference] }\end{array}$ & Research field & Findings & Inferences/ Gaps \\
\hline Xu et al. & $\begin{array}{c}\text { The study was } \\
\text { based on the indoor } \\
\text { air conditions of } \\
\text { enclosed spaces } \\
\text { using Hepa filters } \\
\text { and its effect on } \\
\text { asthmatic children }\end{array}$ & $\begin{array}{c}\text { The research concluded that } \\
\text { the children had no problem } \\
\text { because of the good indoor } \\
\text { air quality maintained by the } \\
\text { hepa filters }\end{array}$ & $\begin{array}{c}\text { There was a confirmation that no particles } \\
\text { smaller than } 50 \text { nanometers were able to } \\
\text { pass through these filters, which made it } \\
\text { comfortable for the asthmatic children. } \\
\text { But the HEPA filters were not able to solve } \\
\text { the problem of the mould growth and the } \\
\text { multiplication of microorganisms inside } \\
\text { the air-conditioner }\end{array}$ \\
\hline
\end{tabular}




\begin{tabular}{|c|c|c|c|}
\hline $\begin{array}{c}\text { Wen et al. } \\
2014^{10}\end{array}$ & $\begin{array}{l}\text { The study tried to } \\
\text { understand the } \\
\text { risks of using HEPA } \\
\text { filters combined } \\
\text { with aerosols, which } \\
\text { improved the indoor } \\
\text { air quality }\end{array}$ & $\begin{array}{l}\text { The effect of such use on the } \\
\text { environment was the basis of } \\
\text { the study.The results showed } \\
\text { that the use of aerosol in } \\
\text { such system is safe, but the } \\
\text { leak of the aerosols into } \\
\text { the environment should be } \\
\text { prevented }\end{array}$ & $\begin{array}{l}\text { The study did not concentrate on the cases } \\
\text { of aerosol leakage or the disposal of used } \\
\text { aerosol which can pose to a health hazard }\end{array}$ \\
\hline $\begin{array}{c}\text { Schweinheim } \\
2015^{9}\end{array}$ & $\begin{array}{l}\text { The research mainly } \\
\text { focussed on the } \\
\text { standards of indoor } \\
\text { air quality and } \\
\text { the application of } \\
\text { hepa filters so as } \\
\text { to achieve those } \\
\text { standards }\end{array}$ & $\begin{array}{l}\text { The test stated that the hepa } \\
\text { filter with class } \mathrm{H} 14 \text { along with } \\
\text { the requirement of EN 1822-4 } \\
\text { and EN } 1822-5 \text { are suitable } \\
\text { for maintaining the highest } \\
\text { quality of indoor air }\end{array}$ & $\begin{array}{l}\text { The installation of hepa filters have to be } \\
\text { done by experienced professionals, any } \\
\text { misalignment in the hepa filters may cause } \\
\text { the germs to pass through. It is also vital } \\
\text { for the filters to be regularly cleaned so as } \\
\text { to maintain the highest standards }\end{array}$ \\
\hline $\begin{array}{l}\text { Zhang and } \\
\text { Jiang } 2016^{8}\end{array}$ & $\begin{array}{l}\text { The research based } \\
\text { on the use of hepa } \\
\text { filters along with } \\
\text { sodium flame } \\
\text { method so as to get a } \\
\text { high quality of indoor } \\
\text { air }\end{array}$ & $\begin{array}{l}\text { The study found out that this } \\
\text { system was safe to be used in } \\
\text { heavy application industries } \\
\text { such as in nuclear power plant } \\
\text { because of the high quality } f \\
\text { indoor air }\end{array}$ & $\begin{array}{c}\text { The environmental effect of using such } \\
\text { combination of hepa filters with sodium } \\
\text { flame was not analysed, and there } \\
\text { was also not much scope for using this } \\
\text { combination in domestic and small scale } \\
\text { applications }\end{array}$ \\
\hline $\begin{array}{l}\text { Barn, } \\
\text { Gombojav, } \\
\text { Ochir, Laagan, } \\
\text { et al. } 2018^{6}\end{array}$ & $\begin{array}{l}\text { Using Hepa filters to } \\
\text { filter out particles so } \\
\text { as to provide a good } \\
\text { environment for } \\
\text { pregnant women by } \\
\text { protecting them from } \\
\text { tobacco smokers }\end{array}$ & $\begin{array}{l}\text { The heap filters used were } \\
\text { able to filter out particles } \\
\text { to the size of } 2.5 \text { PM, which } \\
\text { provided a good comfortable } \\
\text { indoor environment }\end{array}$ & $\begin{array}{l}\text { The study mainly focussed on lowering } \\
\text { the pollutant particle is indoor air, so the } \\
\text { presence of germs in the indoor air has not } \\
\text { been studied }\end{array}$ \\
\hline
\end{tabular}

\section{Discussion}

The review first needs the basic understanding between the two broad types of air-conditioning - the centralised system and the decentralised system. In centralised system, there are duct network or a pipe line which connects multiple indoor units to a single big outdoor unit generally kept on the terrace. The centralised system has air changes, which mean that after every regular interval fresh outside

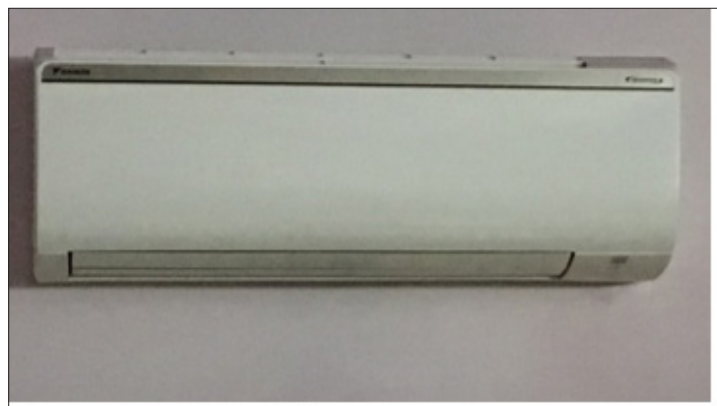

(a) air is drawn in while some indoor air is re-circulated. The decentralised system is mostly used for domestic purposes. The split air-conditioner and the window air-conditioner are types of decentralised system. Split air-conditioner is the only type of HVAC system which does not have a ventilation system. The indoor air is cooled and circulated over and over again. Figure 3 (a) shows the split air-conditioner and 1 (b) shows the filter used in split air-conditioner. This filter is anti-bacterial as used by Daikin split air-conditioners.

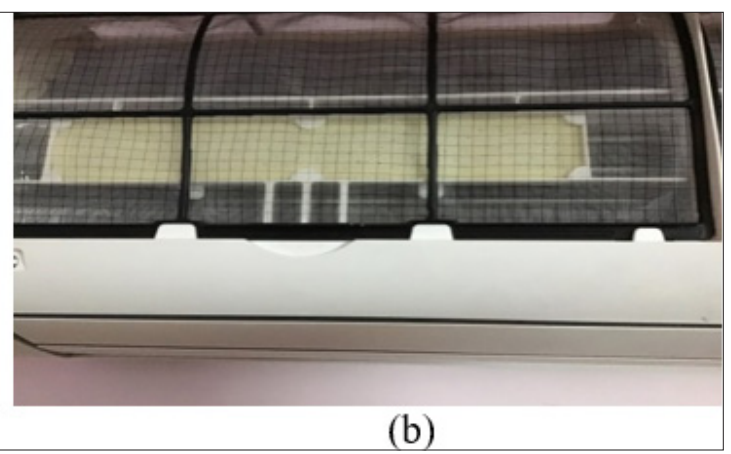

Figure 3.(a): split air-conditioner (b): filter in split AC 
The window air conditioners are used in places where there is a provision of a window. The window air conditioners have the option for ventilation. The ventilation can be manually turned ON or OFF using the ventilation plug provided. Figure 2 (a) shows the window air conditioner and 2 (b) shows the ventilation plug.

In centralised air-conditioner, the outside air is regularly mixed with the circulating indoor air so as to keep the comfort conditions. Because the centralised system covers a large area, it is required to intake a certain amount of fresh air so as to reduce the chance of fungal growth. The centralised system uses heap-filters and other layers of air purification so as to ensure there is no impurity which enters the enclosed area. Figure 5, shows a centralised system and Figure 6 shows the HEPA filters used for air filtration in central air conditioning systems.

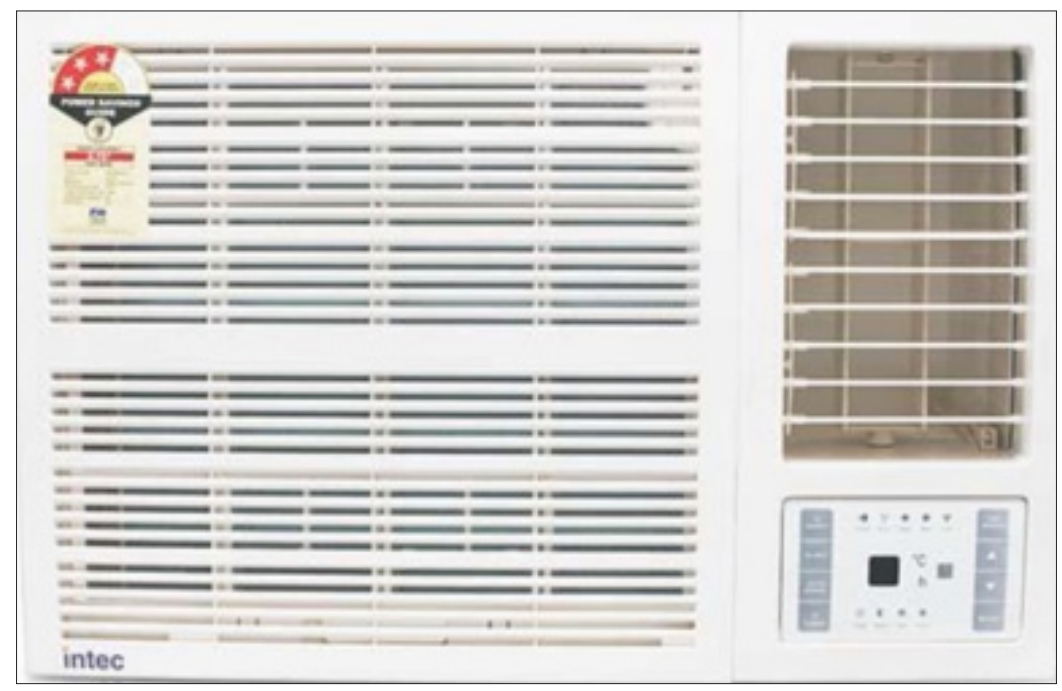

Figure 4.Window air conditioner

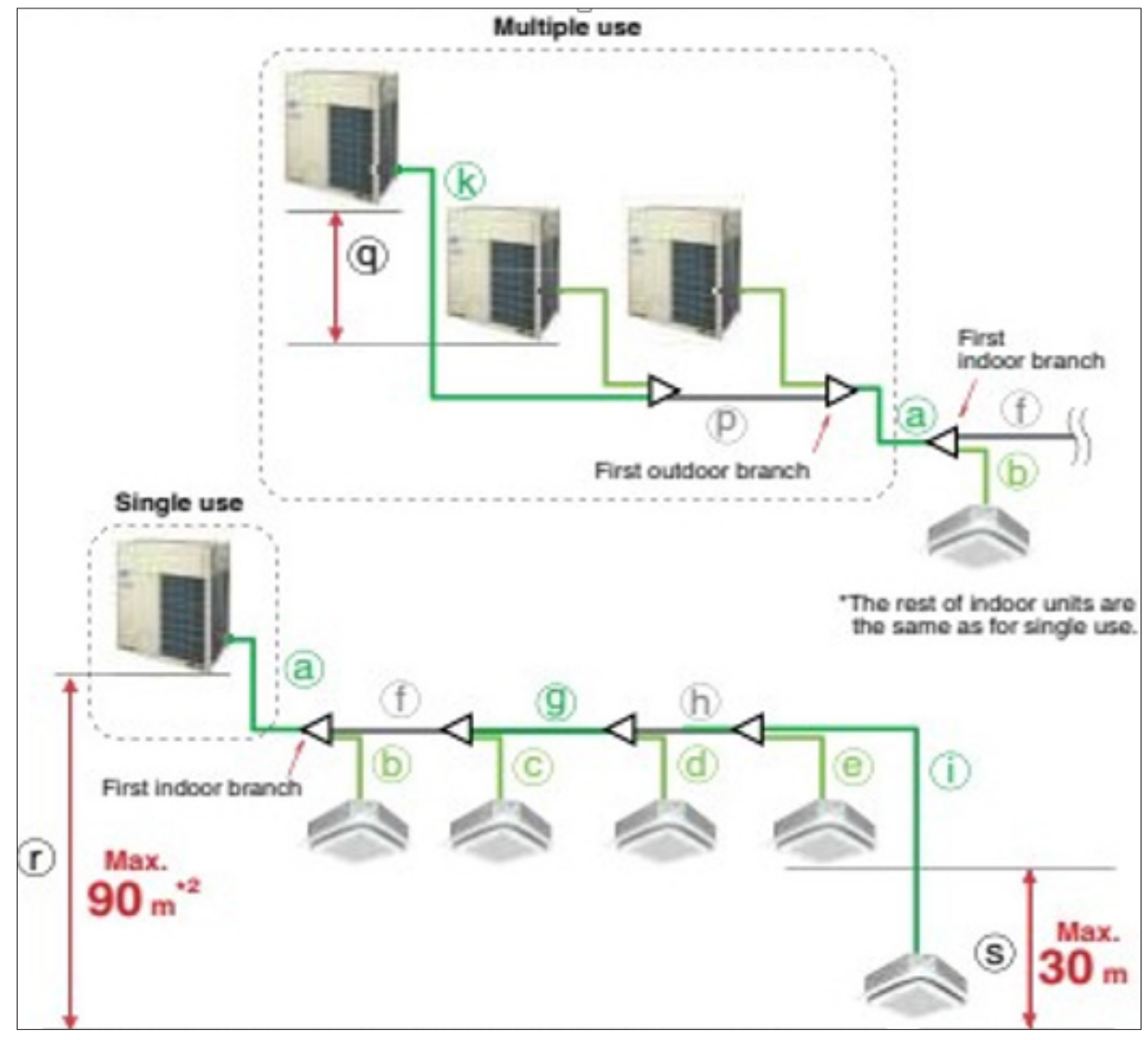

Figure 5.The centralised system 


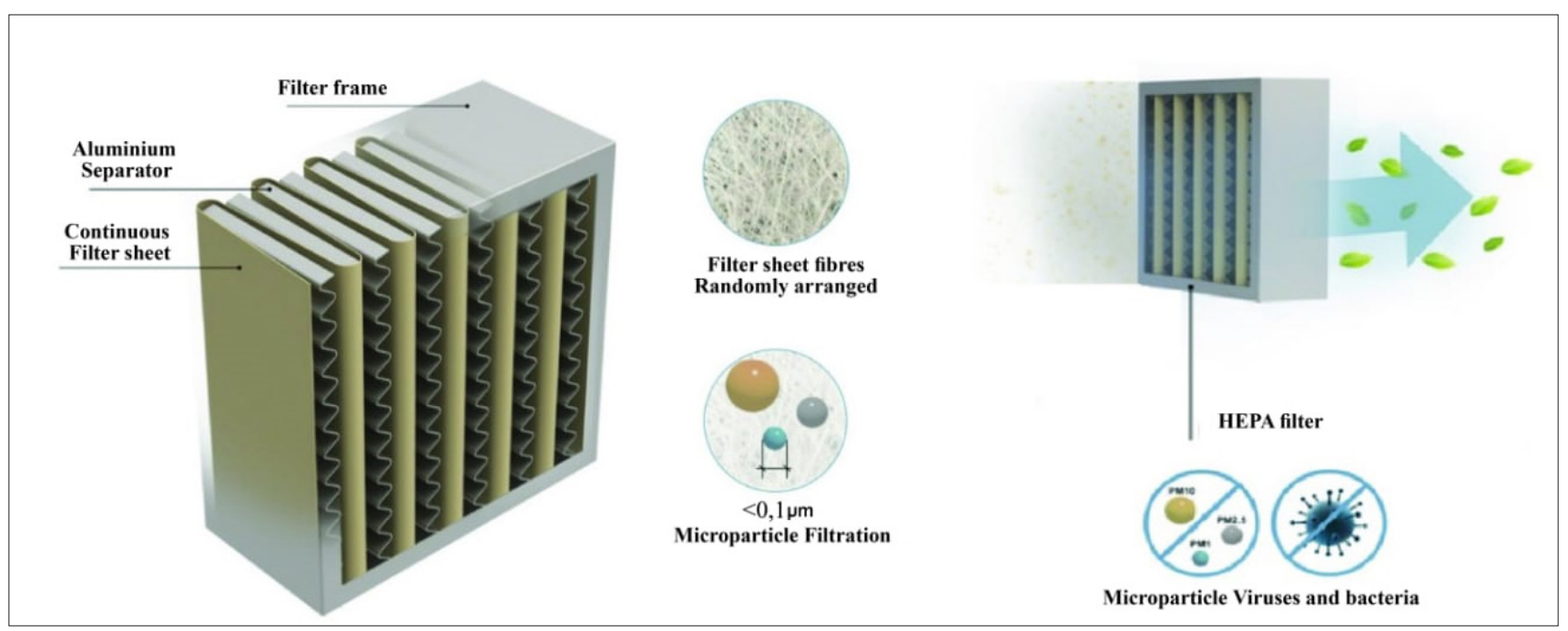

\section{Discussion}

Now that we are all inside our homes, we are still having an uncertainty over ourselves. We are always looking at the possible entries of the virus into our homes. People have been made aware about washing hands and wearing masks. But what if there are still chances for the virus to enter our homes. As stated earlier we have seen that the virus can be airborne and also stay on surfaces. The virus gets airborne when an infected person sneezes, or he spews out molecules from his body. The infected person may not be inside our home but the virus has already become airborne. People inside homes can make sure that no foreign objects enter their homes by cleaning or disinfecting the articles. The other ways now open for the virus is the air. A lot people at homes are using their air conditioners which circulate indoor air through the filter. ${ }^{12}$ Studies have shown that the viruses can range from $20 \mathrm{~nm}$ in diameter to 500 $\mathrm{nm}$. If assumed that the virus currently has a diameter of about 0.125 microns (125 nanometers), ${ }^{13}$ Comparing this to the size of the HEPA filters of air conditioners, the HEPA filters can collect 0.01 microns (10 nanometers) or higher particle-size spectrum. No filtering system has yet been proved to filter COVID-19-because it is a new virus we don't have any studies specifically to test whether a HEPA air purification system eliminates COVID-19 transmission. ${ }^{14}$ The HEPA filters were shown to catch submicron particles up to 0.1 micron by a study of NASA, however, research on the topic is still underway. Testing of such filters is therefore still carried out. ${ }^{15}$

\section{Conclusion}

From the above review it can be said that the air-conditioners are safe to be used during these times. The filters in the HVAC system have the capability to filter out the viruses and other infectious particles to an extent. The air-conditioners which combine hepa filters with anti-bacterial technology are far better than any other filter system. This method of using air conditioners however can still not be considered to be fool proof because the HVAC system does not draw in fresh air in a big volume. Generally $2 / 3^{\text {rd }}$ of the air inside the room is only circulated and only $1 / 3^{\text {rd }}$ air is drawn in for every air change. In case the virus enters the home it may however stay inside for a longer duration. There can also be cases when the virus is present inside a human body but without showing symptoms. Such carrier can spread the virus to other members in the family. A virus could have an incubation period of up to 24 days, so the use of air-conditioners does not dictate the presence or absence of virus. The air-conditioners are for comfort purposes and therefore should not be treated as a method to get rid of impurities or the virus.

\section{Conflicts of Interest: None \\ References}

1. Akhai S, Singh VP, John S. Investigating Indoor Air Quality for the Split-Type Air Conditioners in an Office Environment and Its Effect on Human Performance. Journal of Mechanical Civil Engineering. 2016;13(6):113-118.

2. Akhai S, Mala S, Jerin AA. Apprehending Air Conditioning Systems in Context to COVID-19 and Human Health: A Brief Communication. International Journal of Healthcare Education \& Medical Informatics. 2020;7(1\&2).

3. Blocken B, Malizia F, Van Druenen T, Marchal T. Towards aerodynamically equivalent COVID19 $1.5 \mathrm{~m}$ social distancing for walking and running. Preprint. 2020.

4. Hussain A, Kaler J, Tabrez E et al. Novel COVID-19: A comprehensive review of transmission, manifestation, and pathogenesis. Cureus. 2020;12(5).

5. Chan SK, Du P, Ignacio $C$ et al. Biomimetic Virus-Like Particles as Severe Acute Respiratory Syndrome 
Coronavirus 2 Diagnostic Tools. ACS nano. 2020.

6. Mala S. Myocardial Injury after Non-Cardiac Surgery and Its Correlation with Mortality-A Brief Review on Its Scenario till 2020. International Journal of Preventive Cardiology. 2021;1(1):29-31.

7. Barn P, Gombojav E, Ochir C, et al. The Effect of Portable HEPA Filter Air Cleaner Use during Pregnancy on Fetal Growth: The UGAAR Randomized Controlled Trial. Environment International. 2018;121:981-989. https:// doi.org/10.1016/j.envint.2018.08.036.

8. Zhang Z, Jiang F. In-Place HEPA Filter Testing by the Sodium Flame Method. Powder Technology. 2016;301:615-21. From: https://doi.org/10.1016/j. powtec. 2016.06.046.

9. Schweinheim, Claus. 2015. Setting Standards for HEPA Filter Efficiency. Filtration and Separation. 52(3):13-15. From: https://doi.org/10.1016/S0015-1882(15)301324.

10. Wen Z, Yang W, Li N et al. Assessment of the risk of infectious aerosols leaking to the environment from BSL-3 laboratory HEPA air filtration systems using model bacterial aerosols. Particuology. 2014;13:82-87.

11. Xu Ying, Raja S, Ferro AR et al. Effectiveness of Heating, Ventilation and Air Conditioning System with HEPA Filter Unit on Indoor Air Quality and Asthmatic Children's Health. Building and Environment. 2010;45(2):330337. https://doi.org/10.1016/j.buildenv.2009.06.010.

12. Tanwar N, Akhai S. Survey Analysis for Quality Control Comfort Management in Air Conditioned Classroom. Journal of Advanced Research in Civil and Environmental Engineering. 2017;4(1\&2):20-23.

13. Fehr AR, Perlman S. Coronaviruses: an overview of their replication and pathogenesis. Coronaviruses. 2015;1-23.

14. https://www.vaniman.com/do-hepa-air-purifiers-filterout-the-covid-19-virus/

15. Perry JL, Agui JH, Vijayakimar R. Submicron and nanoparticulate matter removal by HEPA-rated media filters and packed beds of granular materials. 2016.

16. https://twitter.com/AAF_Intl/status/1239986 129396543490/photo/1

17. https://www.airtecnics.com/news/what-are-hepafilters-and-how-do-they-work 